\title{
The Contribution of Syringopeptin and Syringomycin to Virulence of Pseudomonas syringae pv. syringae strain B301D on the Basis of sypA and syrB1 Biosynthesis Mutant Analysis
}

\author{
Brenda K. Scholz-Schroeder, ${ }^{1}$ Michael L. Hutchison, ${ }^{1}$ Ingeborg Grgurina, ${ }^{2}$ and Dennis C. Gross ${ }^{1}$ \\ ${ }^{1}$ Department of Plant Pathology, Washington State University, Pullman 99164-6430, U.S.A.; ${ }^{2}$ Dipartmento di \\ Scienze Biochimiche "A. Rossi Fanelli," Università "La Sapienza" di Rome, Italy \\ Accepted 7 November 2000.
}

\begin{abstract}
Sequencing of an approximately 3.9-kb fragment downstream of the syrD gene of Pseudomonas syringae pv. syringae strain $\mathrm{B301D}$ revealed that this region, designated sypA, codes for a peptide synthetase, a multifunctional enzyme involved in the thiotemplate mechanism of peptide biosynthesis. The translated protein sequence encompasses a complete amino acid activation module containing the conserved domains characteristic of peptide synthetases. Analysis of the substrate specificity region of this module indicates that it incorporates 2,3-dehydroaminobutyric acid into the syringopeptin peptide structure. Bioassay and high performance liquid chromatography data confirmed that disruption of the sypA gene in strain B301D resulted in the loss of syringopeptin production. The contribution of syringopeptin and syringomycin to the virulence of $P$. syringae pv. syringae strain B301D was examined in immature sweet cherry with sypA and syrB1 synthetase mutants defective in the production of the two toxins, respectively. Syringopeptin (sypA) and syringomycin $(\operatorname{syr} B 1)$ mutants were reduced in virulence 59 and $26 \%$, respectively, compared with the parental strain in cherry, whereas the syringopeptin-syringomycin double mutant was reduced $76 \%$ in virulence. These data demonstrate that syringopeptin and syringomycin are major virulence determinants of $P$. syringae pv. syringae.
\end{abstract}

Additional keywords: lipopeptide toxin, necrosis-inducing toxin, nonribosomal peptide synthetase, phytotoxin.

Pseudomonas syringae pv. syringae is a prevalent bacterial plant pathogen with the capacity to incite stem and leaf dis-

Corresponding author: D. C. Gross; Telephone: +1-509-355-1187; Fax: +1-509-335-9541; E-mail: gross@ wsunix.wsu.edu

Current address of M. L. Hutchison: Microbiology Department, ADAS Laboratories, Wergs Road, Wolverhampton, West Midlands WV6 8TQ, England.

Nucleotide and amino acid sequence data was submitted to the GenBank/EMBL database as accession number AF286216.

* The $e$-Xtra logo stands for "electronic extra," indicating that the article online contains color graphics not included in the print edition. eases in numerous monocot and dicot species throughout the temperate regions of the world (Bradbury 1986; Quigley and Gross 1994). A common characteristic of $P$. syringae pv. syringae is the production of two classes of necrosis-inducing lipodepsipeptide toxins, called syringomycins and syringopeptins (Grgurina et al. 1997; Iacobellis et al. 1992b; Quigley and Gross 1994). SRE and $\mathrm{SP}_{22} \mathrm{~A}$ are the major forms of syringomycin and syringopeptin, respectively, produced by $P$. syringae pv. syringae strain B301D. SRE is a cyclic nonapeptide attached to a 3-hydroxy fatty acid tail (Fig. 1A) (Ballio et al. 1988; Fukuchi et al. 1992; Segre et al. 1989), whereas $\mathrm{SP}_{22} \mathrm{~A}$ contains a peptide chain composed of 22 amino acids attached to a 3-hydroxy fatty acid tail (Fig. 1) (Ballio et al. 1991; Ballio et al. 1995).

Previous efforts to elucidate the role of the phytotoxins in plant pathogenesis focused on the biological activities of the two toxins. Syringomycin and syringopeptin are cytotoxic, effectively lyse erythrocytes (Hutchison and Gross 1997; Hutchison et al. 1995; Lavermicocca et al. 1997), inhibit the growth of microorganisms, and exhibit toxicity against plant tissues (Lavermicocca et al. 1997). It is the amphipathic nature of these toxins with their polar peptide head and hydrophobic fatty acid tail that enables them to insert into the plant plasma membrane and form transmembrane pores, permitting ions to flow freely across the membrane (Hutchison and Gross 1997; Hutchison et al. 1995). These passive transmembrane fluxes disrupt the electrical potential across the plant cell membrane, resulting in plant cell death. Only nanomolar amounts of either toxin are necessary to disrupt the membrane and cause an influx of ${ }^{45} \mathrm{Ca}^{2+}$ in tobacco protoplast assays (Hutchison and Gross 1997). Virulent strains of $P$. syringae pv. syringae produce large quantities of syringopeptin and syringomycin in vitro and the toxins are localized to plant tissues infected with $P$. syringae pv. syringae or related pathovars (Fogliano et al. 1999; Grgurina et al. 1997; Paynter and Alconero 1979). In particular, syringopeptin is produced in planta by $P$. syringae pv. lachrymans at a concentration of $0.1 \mathrm{mg}$ per $\mathrm{g}$ of zucchini plant (Curcurbita pepo) tissue (Fogliano et al. 1999). The bulk of syringopeptin and syringomycin is produced in the late-exponential to stationary phase (Grgurina and Mariotti 1999; Lavermicocca et al. 1997; Mo and Gross 1991), although Mo and Gross (1991) demon- 
strated that a $\operatorname{syr} B 1:: l a c Z$ fusion is expressed within $24 \mathrm{~h}$ of inoculation to immature sweet cherry fruits and, therefore, appears to be important during the early stages of phytopathogenesis. This evidence suggests that the toxins are involved in the plant pathogen interaction, but the extent to which each toxin contributes to the virulence of $P$. syringae pv. syringae strain B301D has not been elucidated.

The syringomycin gene cluster encompasses greater than $37 \mathrm{~kb}$ of the genome of $P$. syringae pv. syringae strain B301D (Bender et al. 1999; Guenzi et al. 1998) (Fig. 2). Several genes were isolated and are involved in the production of syringomycin, including $s y r D, s y r P, s y r C, s y r B 1, s y r B 2$, and syrE (Guenzi et al. 1998; Mo and Gross 1991; Quigley and Gross 1994; Zhang et al. 1995; Zhang et al. 1997). Sequence analysis indicated that $s y r D$ codes for a protein that is a member of the ATP-binding cassette (ABC) superfamily of membrane-associated transporter proteins required for the secretion of syringomycin and syringopeptin (Grgurina et al. 1996; Quigley and Gross 1994). The predicted protein sequence of syrP exhibits similarity to the phosphotransfer domains of several proteins, including CheA and KinA, and is hypothesized to be involved in a phosphorelay system of syringomycin regulation (Zhang et al. 1997). The syrC protein contains a thioesterase motif and might function as an acyltransferase (Zhang et al. 1995). The function of the protein translated from $s y r B 2$ is currently unknown, but a functional SyrB2 is required for syringomycin production (B. K. ScholzSchroeder, I. Grgurina, and D. C. Gross, unpublished). The protein products of the $s y r B l$ and $s y r E$ genes are homologous to adenylate-forming enzymes involved in the thiotemplate mechanism of peptide synthesis (Guenzi et al. 1998; Zhang et al. 1995). Although it was shown in biochemical studies that syringopeptin is formed by the thiotemplate mechanism (Grgurina and Benincasa 1994; Grgurina and Mariotti 1999), currently there is no genetic evidence for a thiotemplate mechanism (Bender et al. 1999; Gross et al. 1998).

The thiotemplate mechanism of peptide synthesis utilizes multifunctional enzymes, called peptide synthetases, that catalyze the activation and addition of amino acids to the growing peptide chain (Marahiel et al. 1997). This mechanism has been described in detail for the biosynthesis of many peptide antibiotics, including gramicidin $S$ and surfactin (Menkhaus et al. 1993; Turgay et al. 1992). Peptide synthetases contain repeated amino acid activation modules, which are composed of condensation, amino acid activation, and thiolation domains. The organization of these domains is colinear with the sequence of the growing peptide, with the exception of syringomycin biosynthesis. Syringomycin synthetases do not strictly follow the colinearity rule because $\operatorname{syrB1}$ is located upstream of the $s y r E$ gene. The first module of SyrE activates and binds the N-terminal serine (Guenzi et al. 1998), whereas SyrB1 activates and binds L-threonine (Guenzi et al. 1998), the precursor of 4-chlorothreonine, which is the C-terminal amino acid in syringomycin. The condensation domain of peptide synthetases encompasses approximately 450 amino acids and is characterized by the core sequence HHxxxDG, which is thought to be involved in peptidyl transfer (deCrécyLagard et al. 1995). The amino acid activation domain spans approximately 550 amino acids and is characterized by several core sequences responsible for adenylation of the amino acid. The thiolation domain, encompassing approximately 100 amino acids, follows the amino acid activation domain and contains the thioester-binding motif LGGHS, which binds the 4 '-phosphopantetheine cofactor involved in thioester formation (Fernández-Moreno et al. 1992; Gocht and Marahiel 1994; Marahiel 1992; Stein and Vater 1996).

Analysis of $P$. syringae pv. syringae strain B301D syringomycin mutants revealed that syringomycin is not required for growth in planta or pathogenicity, but it does make a substantial contribution to the virulence of the bacterium in immature sweet cherry fruits (Mo and Gross 1991). P. syringae pv. syringae strains with $s y r B 1$ and $s y r D$ mutations were reduced approximately 30 and $70 \%$ in relative virulence, respectively, compared to the wild-type strain (Mo and Gross 1991). The difference between the $s y r B 1$ and $s y r D$ mutants was surprising because it originally appeared that mutagenesis of either the syrB1 or syrD genes resulted in a comparable effect on toxigenesis. Subsequently, it was determined that the syrD mutants are impaired in their ability to secrete syringomycin and syringopeptin (Grgurina et al. 1996; Quigley et al. 1993), indicating that the decreased virulence of a syrD mutant resulted from defective secretion of the two lipopeptide toxins. Previous studies with $P$. syringae pv. syringae mini Tn5 syringopeptin-syringomycin double mutants demonstrated that they are approximately $70 \%$ less virulent than the wild-type strain (Caponero et al. 1997). These syringopeptin mutants are genetically uncharacterized, but the data suggests that syringopeptin also is an important virulence determinant of $P$. syringae pv. syringae.

Although syringomycin and syringopeptin are highly phytotoxic, this finding alone does not reveal the extent each toxin contributes to the virulence of $P$. syringae pv. syringae in vivo. In order to determine the contribution of each toxin to the virulence of $P$. syringae pv. syringae, each toxin must be removed selectively from the interaction by directed mutation of genes responsible for the biosynthesis of each phytotoxin. A subclone carrying a partial open reading frame (ORF) was identified downstream of $s y r D$, where sequence analysis indicates codes for a peptide synthetase. Mutagenesis of this partial ORF, designated sypA, disrupts the production of syringopeptin by $P$. syringae pv. syringae strain B301D. In this study, we provide evidence that mutations constructed in

A

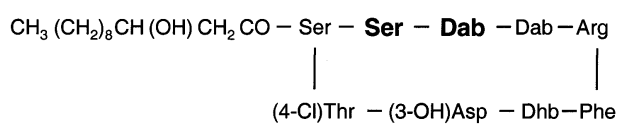

B

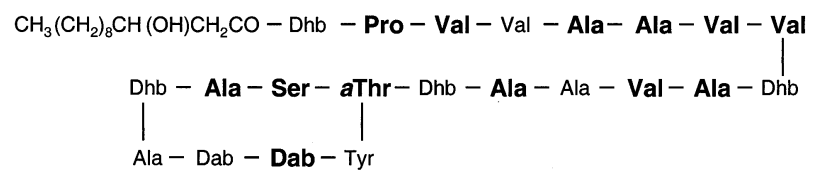

Fig. 1. Structure of $\mathbf{A}$, syringomycin form SRE and $\mathbf{B}$, syringopeptin form $\mathrm{SP}_{22} \mathrm{~B}$, which are the major forms of the toxins produced by $\mathrm{Pseu}$ domonas syringae pv. syringae strain $\mathrm{B} 301 \mathrm{D}$. Dab $=2,4$-diaminobutryic acid; Dhb = 2,3-dehydroaminobutyric acid; $a \mathrm{Thr}=$ allothreonine. Additional amino acids are identified by standard three-letter biochemical notation. D-isomers of the respective amino acids are in bold. 
synthetase genes dedicated to syringopeptin and syringomycin biosynthesis significantly reduce the virulence of $P$. syringae pv. syringae strain B301D in immature sweet cherry fruits.

\section{RESULTS}

\section{Sequence analysis indicates that SypA-M1 is homologous to peptide synthetases.}

Plasmid pYM1 originally was cloned as a 16-kb HindIII fragment from strain B301D by Mo and Gross (1991) and shown to carry several syr genes ( $s y r B 1, s y r B 2, s y r C$, syrD, and $\operatorname{syr} P$ ) (Mo and Gross 1991; Quigley et al. 1993; Zhang et al. 1995; Zhang et al. 1997) within a 7-kb region at one end of the clone. To further characterize the region downstream of the $s y r D$ gene, a 5.1-kb EcoRI-KpnI fragment was subcloned from pYM1 into pUC18 and designated pBS008 (Table 1 and Fig. 2). The nucleotide sequence was determined for a 3,920bp region downstream of syrD on pBS008 (GenBank accession no. AF286216). Analysis revealed the presence of an ORF beginning (ATG) 138-bp downstream of syrD. The ORF is translated in the same direction, but not in the same frame, as $s y r D$. A typical Shine-Dalgarno sequence (GAGAAG) was identified eight nucleotides upstream of the start codon. The ORF was predicted to encode 1,230 amino acids, but neither a stop codon nor a terminator sequence was identified. This indicated that the sypA ORF continues downstream of the pBS008 clone. The ORF was designated sypA on the basis of genotypic and phenotypic evidence (described below) for a role in syringopeptin biosynthesis (Fig. 2).

Analysis of the deduced amino acid sequence for the $\mathrm{N}$ terminal portion of SypA encompassing 1,230 amino acids revealed homology to a family of proteins involved in the thiotemplate mechanism of peptide biosynthesis. This includes homology to multienzymatic proteins involved in peptide antibiotic synthesis in a diversity of bacterial species
(Marahiel et al. 1997; Stein and Vater 1996) as well as proteins responsible for syringomycin biosynthesis in $P$. syringae pv. syringae (Guenzi et al. 1998; Zhang et al. 1995). In particular, the N-terminal portion of SypA shared extensive homology to all eight of the amino acid activation modules encoded by syrE (Guenzi et al. 1998). SyrE is composed of repetitive amino acid activation modules and apparently is responsible for the activation and incorporation of the first eight amino acids to the syringomycin structure (Guenzi et al. 1998). The N-terminal portion of SypA also exhibited extensive homology to other peptide synthetases, including SyrB1 (48\% similarity, $40 \%$ identity), the synthetase with substrate specificity for L-threonine that is modified to 4-chlorothreonine, and the last amino acid in the syringomycin toxin structure (Fig. 3) (Guenzi et al. 1998). In addition, the Nterminal portion of SypA exhibited $47 \%$ similarity and $37 \%$ identity to GrsA (Hori et al. 1989) and $46 \%$ similarity and $36 \%$ identity to the first amino acid activation module of GrsB from Bacillus brevis (Turgay et al. 1992). GrsA and GrsB are multienzymatic peptide synthetases involved in gramicidin $\mathrm{S}$ biosynthesis (Turgay et al. 1992). The extent of the significance of these homologies is evident, considering the calculated $\mathrm{Z}$ scores were greater than 40 (> 6 indicates significance over the first 1,230 amino acids of SypA).

Detailed analysis of the first 1,230 amino acids of the SypA protein revealed the presence of an entire amino acidactivation module, SypA-M1, containing conserved core sequences for the condensation, amino acid activation, and thiolation domains characteristic of all known peptide synthetases that were previously observed for modules associated with SyrB1 and SyrE (Guenzi et al. 1998; Stein and Vater 1996) (Fig. 3). The condensation domain of SypA-M1 consists of a region encompassing approximately 450 amino acids and contains the conserved motif HHIALDG (residues 136 to 142), which has been suggested to be involved in catalyzing

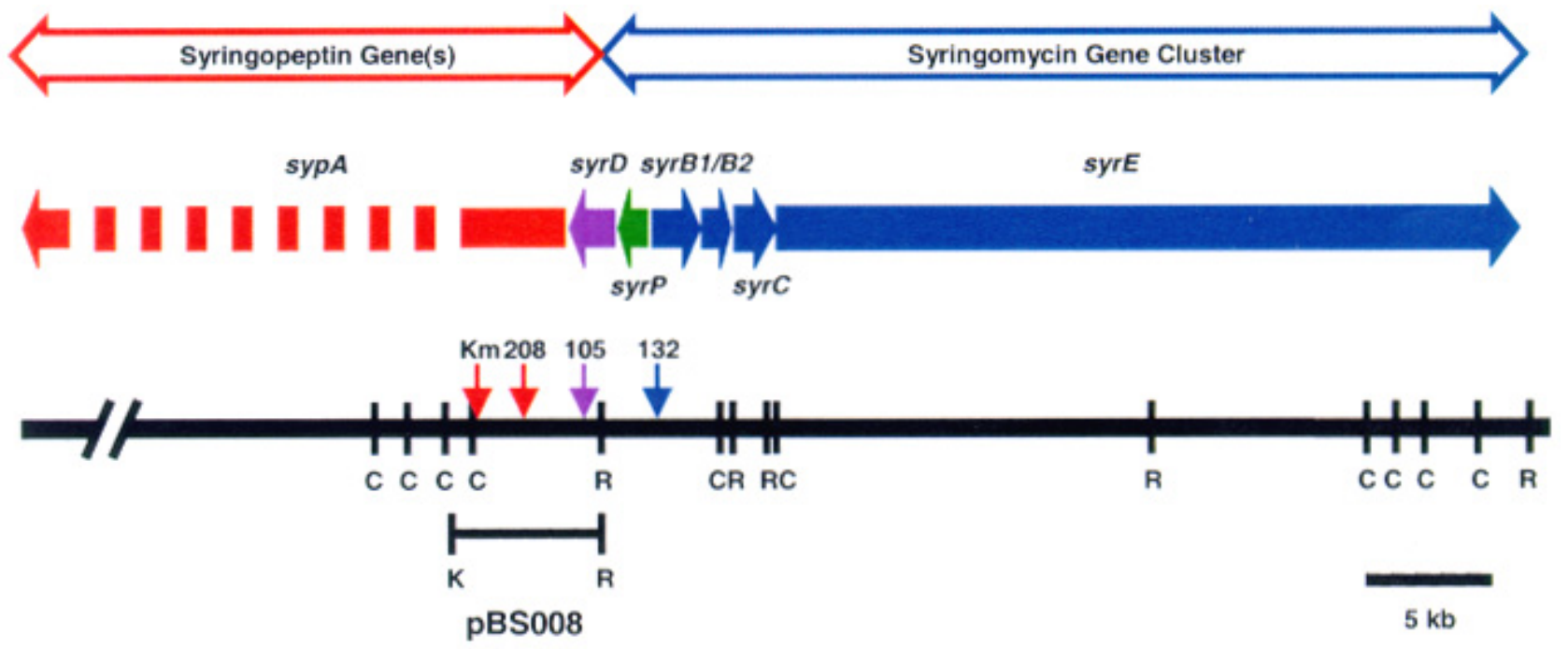

Fig. 2. Map of a 43-kb region on the Pseudomonas syringae pv. syringae strain B301D chromosome containing all of the syringomycin (syr) and a portion of the syringopeptin ( $s y p$ ) biosynthesis genes. Positions and orientations of the $s y r D$, syrP, syrB1, syrB2, syrC, syrE, and $s y p A$ genes as they are organized on the $P$. syringae pv. syringae B301D chromosome are indicated by large arrows. Solid red arrow indicates syringopeptin biosynthesis gene(s), diagonal-lined arrows indicate syringomycin biosynthesis genes, and the purple and green arrows indicate secretion and regulatory genes, respectively. Vertical arrows indicate the positions of the nptII cassette insertion (Km) (red), Tn5 insertion 208 in sypA (208) (red), Tn3HoHo1 insertion 132 in $s y r B 1$ (132) (blue), and Tn3HoHo1 insertion 105 in syrD (105) (purple). Location of the 5.1-kb EcoRI-KpnI fragment carrying the 5' portion of sypA is marked below the genomic map and is designated pBS008. Restriction enzyme sites for EcoRI (R), ClaI (C), and KpnI (K) are identified. 
peptidyl transfer during the peptide chain elongation process (Fig. 3) (deCrécy-Lagard et al. 1995). An amino acidactivation domain follows the condensation domain in SypAM1 on the basis of the occurrence of all five core sequences, described by Marahiel et al. (1997), including the glycine-rich TSGSTGLPKG (residues 610 to 619) motif that resembles the Walker type A motif involved in ATP binding (Gocht and Marahiel 1994; Saraste et al. 1990). In addition, we observed the SGD motif (residues 845 to 847 ), which is the highly conserved core 4 sequence associated with the active site of enzymes involved in binding ATP (Gocht and Marahiel 1994). Finally, the thiolation domain of SypA-M1 contains the thioester-binding motif LGGHS (residues 1,005 to 1,011) responsible for the binding of the $4^{\prime}$-phosphopantetheine cofactor (Fernández-Moreno et al. 1992; Gocht and Marahiel 1994; Marahiel 1992; Stein and Vater 1996).

Another region that forms a putative substrate-binding pocket responsible for amino acid recognition and binding was identified in SypA-M1 (residues 611 to 815) (Conti et al. 1997; Stachelhaus et al. 1999). Phylogenetic analysis of the substrate-binding pockets of the amino acid activation modules SypA-M1, SyrE-M1 through SyrE-M8, and SyrB1-M9 revealed a clustering of modules predicted to bind identical or similar amino acids on the basis of a colinear modular organization of peptide synthesis (Fig. 4). In particular, the substrate-binding pocket of SypA-M1 was most closely related to the substrate-binding pocket of SyrE-M7 (Fig. 4). The significance of this clustering is supported by the bootstrap value
( $100 \%$ on the basis of 1,000 samplings). In addition, the clustering of SyrE-M1 and SyrE-M2 and of SyrE-M3 and SyrEM4 were supported by the bootstrap value $(100 \%$ on the basis of 1,000 samplings) (Fig. 4).

\section{Mutagenesis of $\operatorname{syp} A$ disrupts the production of syringopeptin in $P$. syringae pv. syringae strain B301D and derivatives.}

The sypA gene was disrupted by insertion of either the nptII cassette or a Tn 5 transposon. A nonpolar mutation in sypA was constructed by insertion of the nptII cassette downstream of the start codon of sypA between nucleotides 3,285 and 3,286 . This construct was called pBS029 (Table 1). In contrast, the point of the Tn5 insertion 208 in sypA carried on pYM5.208 was sequenced and found to be located within the sypA ORF between nucleotides 2,114 and 2,115 (Fig. 2). These plasmids were introduced separately into the genomes of $P$. syringae pv. syringae strains $\mathrm{B} 301 \mathrm{D}, \mathrm{B} 301 \mathrm{D}-\mathrm{R}$, and BR334 with marker exchange to generate syringopeptin mutants B301D-Km1, B301D::208, BR208, BR334-Km1, and BR334::208 (Table 1). We then constructed a syringopeptin (sypA::Tn5) and syringomycin (syrB1::Tn3HoHo1) double mutant BR-DBL1 by marker exchange of pBS045 into BR132 (Table 1). Conversely, pYM1.132 was introduced into strain B301D-Km1 to construct B-DBL2, a syringopeptin (sypA$n p t I I)$ and syringomycin (syrBl::Tn3HoHo1) double mutant (Table 1). Southern analysis confirmed the position of all insertions in the $P$. syringae pv. syringae genome.

Table 1. Bacterial strains and plasmids

\begin{tabular}{|c|c|c|}
\hline Strain or plasmid & Relevant characteristics $^{a}$ & Source \\
\hline \multicolumn{3}{|c|}{ Pseudomonas syringae pv. syringae } \\
\hline B301D & Wild type from pear & Cody et al. 1987 \\
\hline B301D-R & Spontaneous Rif ${ }^{\mathrm{r}}$ derivative of B301D & $\mathrm{Xu}$ and Gross 1988 \\
\hline BR132 & syrB::Tn $3 \mathrm{HoHo1}$ derivative of B301D-R; Pip $^{\mathrm{r}} \mathrm{Rif}^{\mathrm{r}}$ & Mo and Gross 1991 \\
\hline B301D::132 & syrB::Tn $3 \mathrm{HoHo} 1$ derivative of $\mathrm{B} 301 \mathrm{D} ; \mathrm{Pip}^{\mathrm{r}}$ & This study \\
\hline BR105 & syrD::Tn $3 \mathrm{HoHo} 1$ derivative of B301D-R; Pip $^{\mathrm{r}}$ Rif $^{\mathrm{r}}$ & Quigley et al. 1993 \\
\hline B301D::105 & syrD::Tn $3 \mathrm{HoHo} 1$ derivative of B301D; $\mathrm{Pip}^{\mathrm{r}}$ & This study \\
\hline BR208 & sypA::Tn5 derivative of $\mathrm{B} 301 \mathrm{D}-\mathrm{R} ; \mathrm{Km}^{\mathrm{r}} \mathrm{Rif}^{\mathrm{r}}$ & This study \\
\hline B301D::208 & sypA::Tn 5 derivative of $\mathrm{B} 301 \mathrm{D} ; \mathrm{Km}^{\mathrm{r}}$ & This study \\
\hline BR334 & syrC::Tn $3 \mathrm{HoHo} 1$ derivative of $\mathrm{B} 301 \mathrm{D}-\mathrm{R} ; \mathrm{Pip}^{\mathrm{r}} \mathrm{Rif}^{\mathrm{T}}$ & Mo and Gross 1991 \\
\hline B301D-Km1 & sypA-nptII derivative of $\mathrm{B} 301 \mathrm{D} ; \mathrm{Km}^{\mathrm{r}}$ & This study \\
\hline BR334::208 & sypA::Tn 5 derivative of $\mathrm{BR} 334 ; \mathrm{Pip}^{\mathrm{r}} \mathrm{Km}^{\mathrm{r}} \mathrm{Rif}^{\mathrm{r}}$ & This study \\
\hline BR334-Km1 & sypA-nptII derivative of BR334; $\mathrm{Pip}^{\mathrm{r}} \mathrm{Km}^{\mathrm{r}} \mathrm{Rif}^{\mathrm{r}}$ & This study \\
\hline A950 & Mini Tn5 derivative of BR334; Pip $^{\mathrm{r}} \mathrm{Km}^{\mathrm{r}} \mathrm{Rif}^{\mathrm{r}}$ & Caponero et al. 1996 \\
\hline A1945 & Mini Tn 5 derivative of BR334; $\operatorname{Pip}^{r} \mathrm{Km}^{\mathrm{r}} \mathrm{Rif}^{\mathrm{r}}$ & Caponero et al. 1996 \\
\hline BR-DBL1 & sypA::Tn5 derivative of BR132; $\mathrm{Pip}^{\mathrm{r}} \mathrm{Km}^{\mathrm{r}} \mathrm{Rif}^{\mathrm{r}}$ & This study \\
\hline B-DBL2 & sypA-nptII and syrB::Tn $3 \mathrm{HoHo} 1$ derivative of B301D; $\mathrm{Pip}^{\mathrm{r}} \mathrm{Km}^{\mathrm{r}}$ & This study \\
\hline BR208-MR501 & Marker rescued strain of BR208 & This study \\
\hline \multicolumn{3}{|l|}{ Escherichia coli } \\
\hline DH5 $\alpha$ & 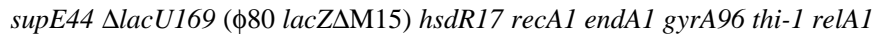 & Hanahan 1985 \\
\hline HB101 & Pro-Leu-Thy ${ }^{-}$Thi $^{-} \mathrm{Sm}^{\mathrm{r}}$ recAl3 & Bolivar et al. 1977 \\
\hline \multicolumn{3}{|c|}{ 1 } \\
\hline pUC18 & High-copy-number cloning vector; $\mathrm{Ap}^{\mathrm{r}}$ & Yanisch-Perron et al. 1985 \\
\hline pBSL15 & nptII gene flanked by inverted pUC18 polylinkers, $\mathrm{Ap}^{\mathrm{r}}, \mathrm{Km}^{\mathrm{r}}$ & Alexeyev 1995 \\
\hline pBR325 & High-copy-number cloning vector; $\mathrm{Cm}^{\mathrm{r}} \mathrm{Tc}^{\mathrm{r}} \mathrm{Ap}^{\mathrm{r}}$ & Prentki et al. 1981 \\
\hline pYM1 & pGS72 carrying a 16-kb HindIII fragment from strain B301D; $\mathrm{Tc}^{\mathrm{r}}$ & Mo and Gross 1991 \\
\hline pYM1.132 & pYM1 $\left(\right.$ syrB::Tn $3 \mathrm{HoHo} 1$ insert 132); $\mathrm{Pip}^{\mathrm{r}} \mathrm{Tc}^{\mathrm{r}}$ & Mo and Gross 1991 \\
\hline pYM1.105 & pYM1 (syrD::Tn3HoHo1 insert 105); Pip $^{\mathrm{r}} \mathrm{Tc}^{\mathrm{r}}$ & Quigley et al. 1993 \\
\hline pYM5.208 & pYM1 (sypA::Tn5 insert 208); $\mathrm{Km}^{\mathrm{r}} \mathrm{Tc}^{\mathrm{r}}$ & $\begin{array}{l}\text { Y.-Y. Mo and D. C. Gross, } \\
\text { unpublished }\end{array}$ \\
\hline pBS008 & pUC18 carrying a 5.1-kb EcoRI-KpnI fragment of pYM1; $\mathrm{Ap}^{\mathrm{r}}$ & This study \\
\hline pBS029 & pBS008 with nptII inserted into EcoRV site; $\mathrm{Ap}^{\mathrm{r}} \mathrm{Km}^{\mathrm{r}}$ & This study \\
\hline pBS045 & pBR325 carrying a 10.6-kb EcoRI-EcoRV fragment of pYM5.208; Tc ${ }^{\mathrm{r}}$ & This study \\
\hline
\end{tabular}

${ }^{a} \mathrm{Ap}^{\mathrm{r}}, \mathrm{Km}^{\mathrm{r}}, \mathrm{Pip}^{\mathrm{r}}, \mathrm{Cm}^{\mathrm{r}}, \mathrm{Tc}^{\mathrm{r}}$, and $\mathrm{Rif}^{\mathrm{r}}=$ resistance to ampicillin, kanamycin, piperacillin, chloramphenicol, tetracycline and rifampicin, respectively. 
P. syringae pv. syringae mutant strains were screened for production of syringopeptin and syringomycin by plate bioassays with Bacillus megaterium $\mathrm{Km}$ and Geotrichum candidum F-260 as indicator organisms. Strains B301D, B301D-R (Fig. 5, row A), BR132 (Fig. 5, row B), B301D-Km1, B301D::208, and BR208 (Fig. 5, row C) produced zones of inhibition approximately 8 to $10 \mathrm{~mm}$ in radius to $B$. megaterium. Inhibition of $B$. megaterium by strains B301D::208 and BR208 was a result of production of high quantities of syringomycin (Lavermicocca et al. 1997). Strain BR334, a syrC mutant, produced even larger zones of inhibition with the radius of the zone reaching $12 \mathrm{~mm}$ (data not shown). Strains BR132 and BR334 do not produce zones of inhibition when oversprayed with $G$. candidum, indicating syringomycin production was disrupted (Fig. 5). Strains B301D, B301D-R, B301D-Km1, B301D::208, and BR208 produced zones approximately 10 to $12 \mathrm{~mm}$ in radius when oversprayed with $G$. candidum. In contrast, the syringopeptin and syringomycin double mutant strains BR-DBL1 (Fig. 5, row D), B-DBL2, BR334-Km1, and BR334::208 produced no zones of inhibition to either $B$. megaterium or G. candidum. If the sypA::Tn5 or sypA-nptII mutation was introduced into a $P$. syringae pv. syringae strain that produced syringomycin, wild-type zones of inhibition to $B$. megaterium were observed when the resultant strains were oversprayed. Whenever the sypA::Tn5 or sypA-nptII mutation was introduced into a $P$. syringae pv. syringae strain carrying a syringomycin mutation, the strain produced no zones of inhibition to either B. megaterium or G. candidum (Fig. 5). Finally, strain BR105 (Fig. 5, row E) (Quigley et al. 1993), which is a $s y r D$ mutant affected in secretion of syringopeptin and syringomycin (Grgurina et al. 1996), produced small zones of inhibition to G. candidum and slightly reduced zones of inhibition to $B$. megaterium. In bioassays, the $s y r B 1$ mutant

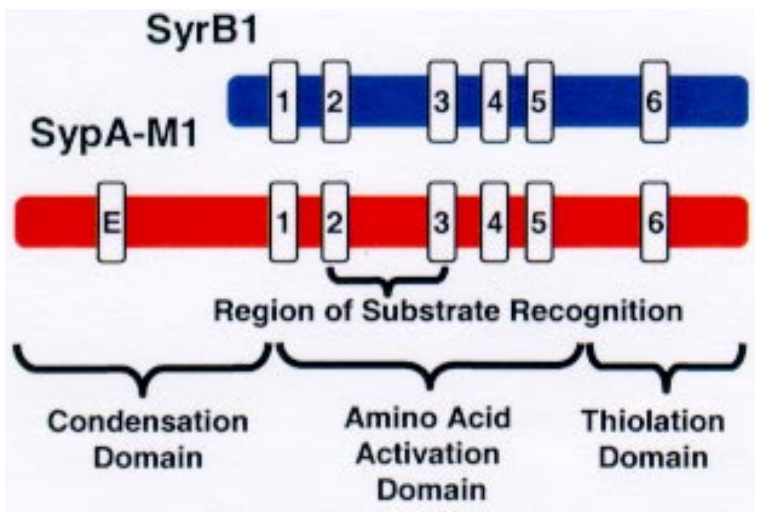

Fig 3. Alignment of the predicted amino acid activating modules of SyrB1 (blue) and the first module of SypA (i.e., SypA-M1) (red), illustrating the three domains characteristic of peptide synthetases as defined by Stein and Vater (1996). The SypA-M1 module is hypothesized to be the first module of a syringopeptin synthetase and is composed of an elongation domain, an amino acid activation domain, and a thiolation domain. SyrB1-M9 is the last module of syringomycin biosynthesis and lacks an elongation domain. The predicted region of substrate recognition is identified between core sequences 2 and 3 in SyrB1 and SypA1. Elongation domain contains the characteristic HHxxxDG motif (E). Amino acid activation domain contains five conserved core sequences as described by Stachelhaus and Marahiel (1996). Core 2 corresponds to the Walker type A motif involved in ATP binding, the motif of core 4 is associated with ATPase activity, and cores 3 and 5 are predicted to be involved in catalyzing aminoacyl adenlyate formation. Core 6 , identified by a characteristic LGGHSL motif, is located in the thiolation domain. strains (BR132, B301D::132) produced wild-type levels of syringopeptin, whereas the sypA mutant strains (BR208, B301D::208, B301D-Km1) produced wild-type levels of syringomycin (data not shown).

High performance liquid chromatography (HPLC) analysis of metabolites produced by $P$. syringae pv. syringae strain B301D and mutant derivatives verified results observed in bioassays. Strain B301D produces syringopeptin forms $\mathrm{SP}_{22} \mathrm{~A}$ and $\mathrm{SP}_{22} \mathrm{~B}$ and syringomycin forms SRE and SRG (Grgurina et al. 1996). Characteristic peaks on the chromatograph were observed at 20 and $21 \mathrm{~min}$ (77 to $88 \%$ solvent $\mathrm{B}$ ) for $\mathrm{SP}_{22} \mathrm{~A}$, respectively, and for $\mathrm{SP}_{22} \mathrm{~B}$, at 12 and $14 \mathrm{~min}(52 \%$ solvent $\mathrm{B})$ for SRE and SRG, respectively (data not shown). Analysis of the $P$. syringae pv. syringae strain B301D derivatives carrying mutations in the sypA gene (Table 1) determined that they no longer produce the characteristic peaks for $\mathrm{SP}_{22} \mathrm{~A}$ and $\mathrm{SP}_{22} \mathrm{~B}$. In addition, HPLC analysis of metabolites produced by B301D mutant derivatives carrying mutations in the syrB1

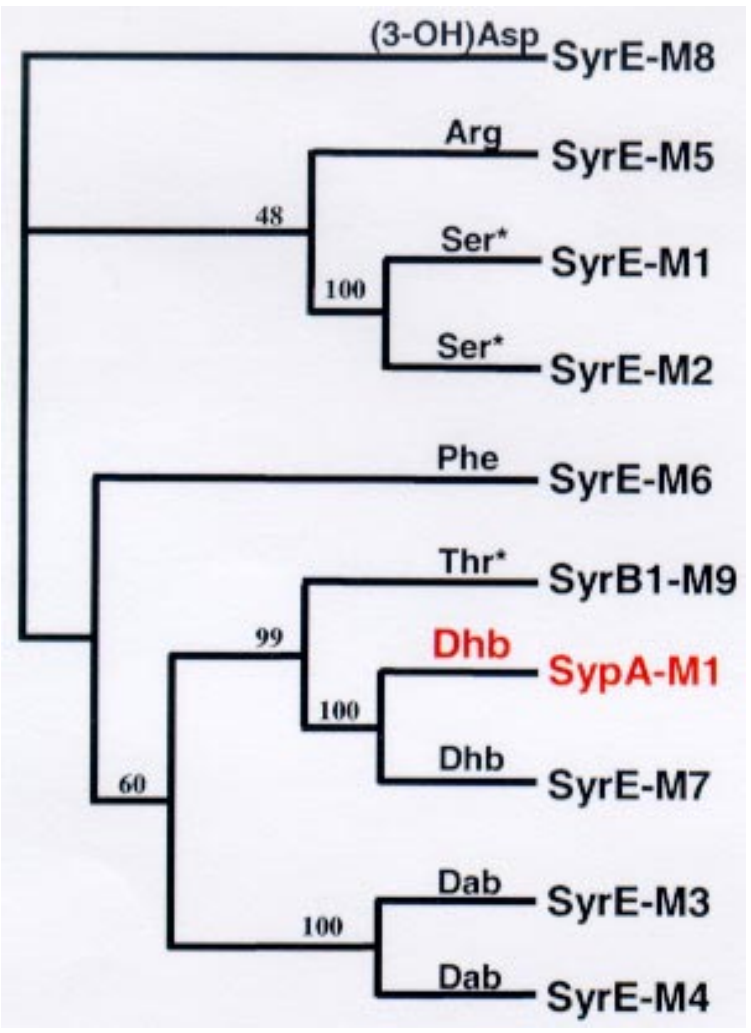

Fig. 4. Dendrogram representing the phylogenetic relationship of the putative substrate-binding region of peptide synthetases. The putative substrate-binding region of the SypA-M1 (residues 618 to 815) was aligned by the Kimura Model with the putative substrate-binding regions of the amino acid activating modules of SyrB1 and SyrE, as described in text. Clustering observed reflects the putative substrates incorporated by the various modules. Numbers at the nodes indicate the levels of bootstrap support on the basis of neighbor-joining analysis of 1,000 resampled data sets; values greater than $40 \%$ are given. Amino acids marked with asterisks were the substrates for their respective substrate-binding regions (Guenzi et al. 1998). SypA-M1 = first amino acid activating module of the SypA protein; SyrE-M1 to SyrE-M8 = respective amino acid activating modules of the SyrE protein (Guenzi et al 1998); SyrB1-M9 = amino acid activation module of SyrB1 (Zhang et al. 1995); $\mathrm{Dab}=2,4$-diaminobutryic acid; Dhb = 2,3-dehydroaminobutyric acid. Additional amino acids are identified by standard threeletter biochemical notation. 
gene demonstrated that they no longer produce characteristic peaks for SRE and SRG (data not shown).

Complementation of the mutant strain BR208 was accomplished by marker rescue with a portion of the wild-type sypA carried on pYM1. Southern analysis with the nptII gene confirmed that the Tn5 insertion was no longer present in the recovered strain BR208-MR501 (Table 1). Cherry virulence assays confirmed that strain BR208-MR501 recovered the capability of wild type virulence.

\section{HPLC-purified syringomycin and syringopeptin} rapidly induce necrosis on immature sweet cherry fruits.

HPLC-purified syringomycin and syringopeptin rapidly produced extensive necrosis on immature sweet cherry fruits (Fig. 6). The immature fruits were treated at three wound sites with $2.5 \mu \mathrm{g}$ of purified syringomycin or syringopeptin. A rapid necrosis developed in cherry fruits within $5 \mathrm{~h}$ after treatment with either of the phytotoxins. The necrotic lesions were approximately $3 \mathrm{~mm}$ in diameter in response to either of the purified phytotoxins. In comparison, little to no response was observed on cherry fruits inoculated with the water control. The necrotic response observed as a result of the addition of purified syringopeptin and syringomycin is comparable with the observed necrosis of cherry fruits after several days of incubation with $P$. syringae pv. syringae strain B301D (Quigley et al. 1993).

\section{sypA mutant was less virulent than syrB1 mutant on immature sweet cherry fruits.}

Syringopeptin and syringomycin mutant strains of $P$. syringae pv. syringae were inoculated onto immature sweet cherry fruits and evaluated for relative virulence (Fig. 7). Strain BR208 (Figs. 7C and 8C), a sypA-Tn5 mutant, was significantly reduced in virulence by approximately $59 \%(P=0.05)$ compared with parental strain B301D-R (Figs. 7A and 8A). In contrast, the syrB1 syringomycin mutant strain BR132 (Figs. $7 \mathrm{~B}$ and $8 \mathrm{~B})$ was significantly reduced by $26 \%(P=0.05)$ in virulence compared with parental strain B301D-R. The sypAsyrB1 double-mutant strain BR-DBL1 (Figs. 7D and 8D) was reduced in virulence by approximately $76 \%$ compared with B301D-R and was less virulent $(P=0.05)$ than BR208 and BR132. Likewise, two additional syr-syp double mutants, A959 and A1945, were not different statistically $(P=0.05)$ from BR-DBL1 in virulence in immature sweet cherry fruits (data not shown) on the basis of a $70 \%$ reduction in virulence (Caponero et al. 1997). Mutant BR-DBL1 was consistently less virulent than the syringopeptin mutant, producing very small and restricted lesions on the cherry fruits, but the difference was not significant. The $\operatorname{syr} D$ secretion mutant BR105 (Figs. 7E and 8E), which apparently functions in export of syringopeptin and syringomycin (Grgurina et al. 1996), was slightly higher than the syr-syp double mutants in virulence. The virulence of the recovered strain BR208-MR501 (Figs. $7 \mathrm{G}$ and $8 \mathrm{~F}$ ) was at wild-type levels and not significantly different from the parental strain B301D-R. In 1998, this experiment was repeated six times with immature cherries of the cultivar Bing and twice with cultivar Chinook (data not shown) at different developmental stages of the cherry fruits. This experiment was repeated in 1999 and 2000 with immature Bing cherries. Similar results were observed in each experiment. No statistical differences in virulence were observed between the mutants with $P$. syringae pv. syringae strain B301D and B301D-R backgrounds.

Bacterial populations from inoculated immature cherry fruits of strains BR208 (sypA), BR132 (syrB1), BR-DBL1 (sypA-syrB1), and BR105 (syrD) were not significantly different at day $4(P=0.05)$ from those of strain B301D-R. The bacterial population of each strain recovered from cherry fruits was approximately $1 \times 10^{8} \mathrm{CFU}$ per fruit (data not shown).

\section{DISCUSSION}

The production of lipopeptide toxins is a distinctive feature of $P$. syringae pv. syringae and has long been purported to have a significant role in plant pathogenesis. As with many phytotoxins, there is considerable debate concerning their actual contribution to disease development. In the case of $P$. syringae pv. syringae, this debate is heightened because two classes of lipopeptide phytotoxins that exhibit nonspecific necrosis-inducing activity to plant cells are produced. It is well established that $P$. syringae pv. syringae strain B301D produces large amounts of syringopeptin and syringomycin in vitro (Grgurina et al. 1996). For example, strain B301D produces greater than $10 \mathrm{nmol}$ of syringomycin per $\mathrm{ml}$ and $2 \mathrm{nmol}$ of syringopeptin per $\mathrm{ml}$ in broth culture during the log and early stationary phases (Grgurina et al. 1996). It also is recognized that syringopeptin and syringomycin are produced in diseased plant tissue (Fogliano et al. 1999; Grgurina et al. 1997). In particular, Fogliano et al. (1999) detected approximately $0.1 \mathrm{mg}$ of syringopeptin per $\mathrm{g}$ of fresh zucchini tissue (Cucurbita pepo cv. Striata d'Italia) infected with $P$. syringae pv. lachrymans by enzyme-linked immunosorbent assay. The ability to detect both toxins in infected plant tissue is evidence that substantial quantities of both toxins are produced in

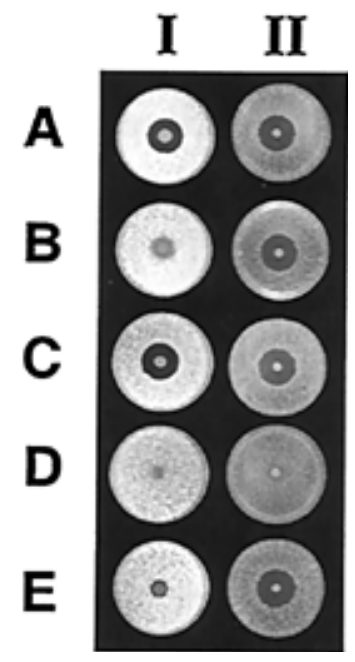

Fig. 5. Syringopeptin and syringomycin plate bioassays of the Pseudomonas syringae pv. syringae strains. Column I contains PDA plates in which different $P$. syringae pv. syringae strains were incubated for 4 days and oversprayed with Geotrichum candidum. Column II contains PGNA plates with different $P$. syringae pv. syringae strains that were incubated for 4 days and then oversprayed with Bacillus megaterium. This is the standard bioassay for syringomycin and syringopeptin respectively, as described in text. Row A, B301D-R (parental); B, BR132 (syrB1 mutant); C, BR208 (sypA mutant); D, BR-DBL1 (syrB1-sypA double mutant); E, BR105 (syrD mutant). 
planta (Fogliano et al. 1999; Grgurina et al. 1997; Paynter and Alconero 1979). Furthermore, these metabolites are extremely phytotoxic (Hutchison and Gross 1997; Iacobellis et al. 1992a; Lavermicocca et al. 1997), which indicates that both toxins have a significant role in disease development. Kauss et al. (1991) observed that syringomycin at concentrations as low as $200 \mathrm{ng}$ per $\mathrm{ml}$ can induce leakage of $\mathrm{K}^{+}$and $\mathrm{Ca}^{2+}$ in $\mathrm{Ca}$ tharanthus roseus suspension cells, and Mott and Takemoto (1989) reported reductions in stomatal apertures in Vicia faba epidermis after treatment with $120 \mathrm{ng}$ of syringomycin per ml. Hutchison and Gross (1997) demonstrated that lysis of tobacco protoplasts occurred at a threshold of $50 \mathrm{ng}$ of either syringomycin or syringopeptin per ml. In this study, the application of $2.5 \mu \mathrm{g}$ of purified syringopeptin or syringomycin preparations to immature sweet cherry fruits effectively reproduced the necrotic symptoms associated with infection by $P$. syringae pv. syringae in less than $5 \mathrm{~h}$ (Fig. 6). It was evident that only small amounts of the toxin are necessary to produce extensive tissue necrosis. These experiments demonstrate that both toxins are highly phytotoxic and produced during the plant-pathogen interaction but do not effectively measure the relative contribution of each toxin to plant disease development.

The introduction of mutations that specifically disrupt toxin biosynthesis genes yielded $P$. syringae pv. syringae strains that fail to produce one or both of the lipopeptide toxins. Subsequent evaluation of the virulence of each respective strain in immature sweet cherry fruits established that syringomycin contributes to the virulence of $P$. syringae pv. syringae (Bender et al. 1999; Mo and Gross 1991; Xu and Gross 1988), but this work was completed before syringopeptin was isolated and characterized by Ballio et al. (1991). Caponero et al. (1997) tested syringopeptin mutants for effects on virulence,

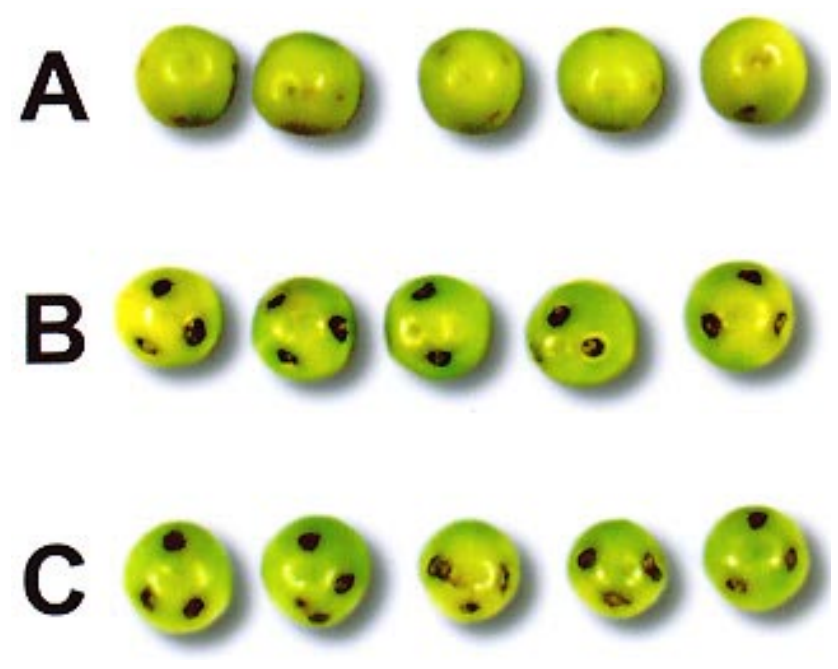

Fig 6. Comparison of the phytotoxic effects of syringomycin and syringopeptin in immature sweet cherry fruits cultivar Bing. Fruits were wounded at three sites. Each wound was treated with $2.5 \mu \mathrm{g}$ of syringomycin or syringopeptin purified by high performance liquid chromatography from culture extracts of Pseudomonas syringae pv. syringae strain B301D. Cherry fruits were incubated at $20^{\circ} \mathrm{C}$ in a moist chamber and photographed $5 \mathrm{~h}$ after exposure to the toxins. Row A, sterile water control; B, syringomycin (mixture of forms $\mathrm{SRA}_{1}$, SRE, and SRG); $\mathrm{C}$, syringopeptin (mixture of forms $\mathrm{SP}_{22} \mathrm{~A}$ and $\mathrm{SP}_{22} \mathrm{~B}$ ). but the mutations used to disrupt syringopeptin were not genetically characterized and shown to specifically target toxin biosynthesis. In this study, the $5^{\prime}$ region of the sypA gene dedicated to the biosynthesis of syringopeptin was disrupted in $P$. syringae pv. syringae strain B301D. The P. syringae pv. syringae sypA mutant strains did not produce syringopeptin and were significantly reduced in virulence relative to the parental strain. In particular, the $P$. syringae pv. syringae syringopeptin mutant strains BR208 and B301D-Km1 were reduced $59 \%$ in virulence, and syringopeptin-syringomycin double-mutant strains BR-DBL1 and B-DBL2 were reduced $76 \%$ in virulence in immature sweet cherry fruits compared with the parental strain B301D-R in cherry pathogenicity tests (Figs. 7 and 8). The virulence assays demonstrated the importance of syringopeptin in the development of disease symptoms. Nevertheless, the contribution of syringopeptin and syringomycin to virulence is not additive on the basis of the cherry virulence assays (Figs. 7 and 8). In addition, the reduction in virulence observed for sypA mutants is not the result of a polar mutation because the polar (BR208 and BRDBL1; Tn5 insertion) and nonpolar (B301D-Km1 and BDBL2; nptII cassette insertion) mutants were equivalent in cherry virulence assays (data not shown). The $P$. syringae pv. syringae syrD mutant (BR105) was reduced approximately $73 \%$ in virulence relative to the parental strain in immature

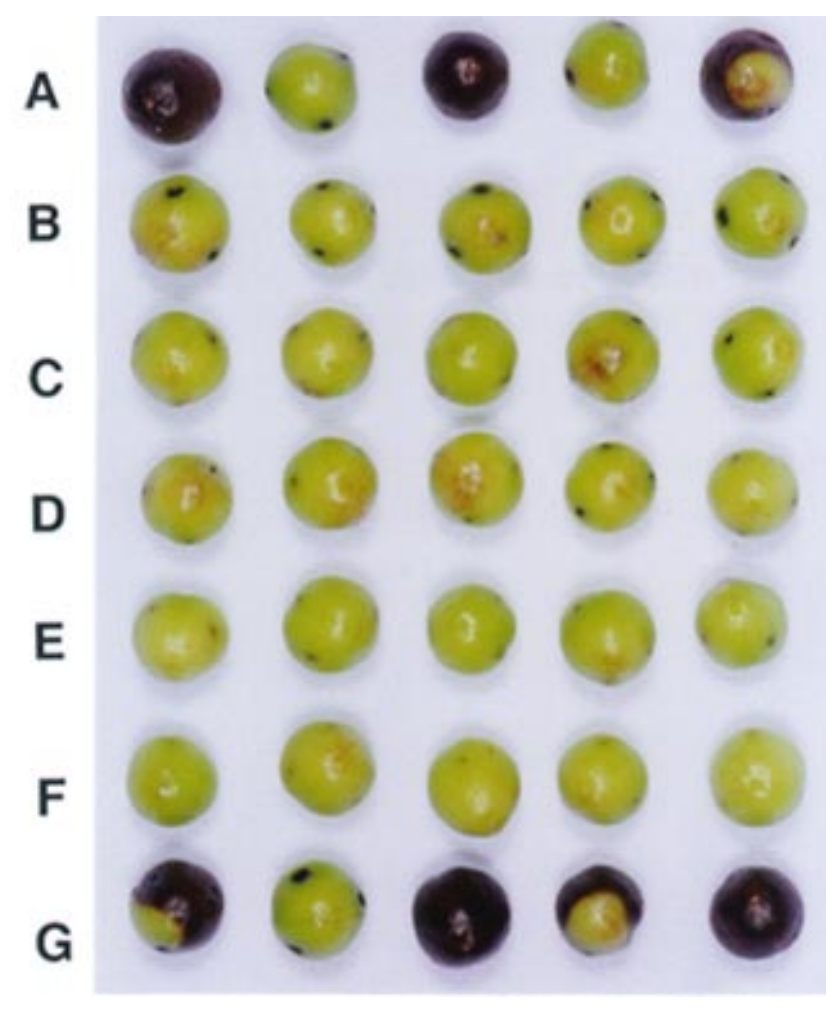

Fig. 7. Necrotic lesions formed in immature sweet cherry fruits cultivar Bing by mutant strains of Pseudomonas syringae pv. syringae defective in syringomycin, syringopeptin, or both compared with parental strain B301D-R. Fruits were punctured at three sites and inoculated at each site with a $2.5-\mu 1$ droplet containing approximately $5 \times 10^{4}$ cells. Symptoms were observed 4 days after the fruits were incubated in a moist chamber at $20^{\circ} \mathrm{C}$. Row A, B301D-R (parental strain); B, BR132 (syrB1 mutant); C, BR208 (sypA mutant); D, BR-DBL1 (syrB1-sypA double mutant); E, BR105 (syrD mutant); F, water control; G, BR208-MR501 (rescued strain). 
sweet cherry fruit (Figs. 7 and 8) (Quigley et al. 1993). This is similar to the reduction in virulence observed for the syringopeptin-syringomycin double mutants. The syrD gene codes for an ABC transporter, and strain BR105 is defective in the secretion of both toxins (Grgurina et al. 1996). Consequently, it was not surprising to observe that strain BR105 was comparable to that of the syringopeptin-syringomycin double mutants BR-DBL1 and B-DBL2. Thus, syringopeptin and syringomycin are major virulence determinants of $P$. syringae pv. syringae strains that are capable of infecting members of the Prunus spp. such as sweet cherry.

The contribution of syringopeptin to virulence of $P$. syringae pv. syringae appears to be greater than that of syringomycin on the basis of pathogenicity tests in immature sweet cherry fruits, which could be the result of the different phytotoxic capabilities of the two phytotoxins. Syringopeptin and syringomycin exhibit differential antifungal and antibacterial activity against a variety of microorganisms (Iacobellis et al. 1992a; Lavermicocca et al. 1997). Iacobellis et al. (1992a) reported that syringopeptin is more phytotoxic than syringomycin, but this differential phytotoxic capability was not observed by Hutchison and Gross (1997), who reported equivalent tobacco protoplast lysing activity for syringopeptin and syringomycin at a threshold concentration of $50 \mathrm{ng}$ per $\mathrm{ml}$. It is the amphipathic nature of these phytotoxins that allows them to insert into plant cell membranes, disrupt the ionic potential, and cause cell death. The application of the purified toxins can induce necrosis very rapidly in cherry fruits (Fig. 5). It has been proposed that fewer syringopeptin monomers ( $5 \pm 1$ monomers) are required for pore formation compared with syringomycin ( $6 \pm 1$ monomers). On the basis of this criteria, syringopeptin is the more potent phytotoxin (Dalla Serra et al. 1999; Hutchison and Gross 1997). Consequently, the difference in numbers of toxin molecules required to form a pore in the plant cell membrane is likely reflected in their respective contribution to the virulence of $P$. syringae pv. syringae.

Pseudomonas syringae pathovars are known to produce a wide spectrum of secondary metabolites that exhibit phytotoxic capabilities (Bender et al. 1999; Gross 1991), thus the actual contribution of a phytotoxin depends on the specific host-pathogen interaction. Many pathovars of Pseudomonas syringae produce toxins that exhibit phytotoxic capabilities, including $P$. syringae pv. phaseolicola and $P$. syringae pv. tomato, which produce phaseolotoxin and coronatine, respectively. The production of phaseolotoxin by $P$. syringae pv. phaseolicola is responsible for the development of a chlorotic halo around the lesion and contributes to the ability of the strain to spread systemically in bean. Phaseolotoxin production, however, neither affects lesion size on bean leaves nor the ability to grow in plant tissues (Peet et al. 1986). Coronatine is produced by several $P$. syringae pathovars, including P. syringae pv. tomato (Bender et al. 1987). In tomato leaves, analysis of coronatine mutants of $P$. syringae pv. tomato demonstrated that the toxin is not essential for pathogenicity. Nevertheless, coronatine biosynthesis mutants produced lesions that were reduced $33 \%$ compared with the wild-type strain. Cell populations of coronatine mutants in tomato leaves were reduced almost two log units compared with the wild-type strain (Bender et al. 1987). It is evident from these studies that each toxin contributes to the virulence of the pathogen. Con- sequently, syringopeptin and syringomycin have important roles in pathogenesis, as has been observed for many of the phytotoxins produced by $P$. syringae pathovars.

Analysis of the 3.9-kb region encompassing the $5^{\prime}$ end of sypA indicates that this gene codes for a peptide synthetase dedicated to the biosynthesis of syringopeptin via the thiotemplate mechanism (Fig. 3) (Stachelhaus and Marahiel 1995; Stein and Vater 1996). The predicted N-terminal portion of the SypA protein is homologous to proteins that function as peptide synthetases in antibiotic, siderophore, and phytotoxin biosynthesis (Stachelhaus and Marahiel 1995; Stein and Vater 1996). In particular, the N-terminal portion of SypA exhibits extensive homology to SyrB1 and the amino acid activation modules of SyrE, synthetases required for the biosynthesis of syringomycin (Guenzi et al. 1998; Zhang et al. 1995). This Nterminal portion of the SypA protein encompasses the first amino acid activation module and contains the predicted domains for condensation, amino acid activation, and thiolation that is characteristic of peptide synthetases (Stein and Vater 1996). This provides what we believe is the first genetic evidence that syringopeptin is synthesized by the thiotemplate mechanism of biosynthesis. Accordingly, one can predict that at least $68 \mathrm{~kb}$ of DNA will be required to code for the synthetase(s) necessary for syringopeptin biosynthesis on the basis that approximately $3 \mathrm{~kb}$ of DNA is necessary to code for each amino acid activation module and one amino acid activation module is required for the addition of each of the 22 amino acids in the syringopeptin structure (Stein and Vater 1996).

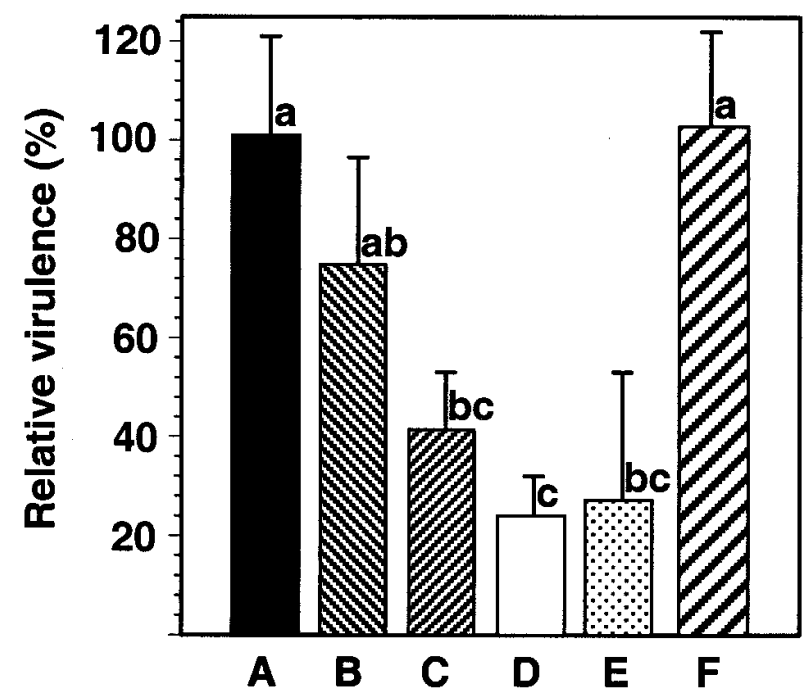

Fig. 8. Relative virulence of Pseudomonas syringae pv. syringae mutants in immature sweet cherry fruits cultivar Bing measured by lesion size. Immature sweet cherry fruits were punctured at three sites and inoculated at each site with a $2.5-\mu 1$ droplet containing approximately $5 \times 10^{4}$ cells. Fruits were incubated for 4 days at $20^{\circ} \mathrm{C}$ in a moist chamber, and virulence was measured as the diameter of the lesion. Relative virulence of the mutants is presented as percent virulence relative to parental strain B301D-R. Differences between treatments were determined by analysis of variance followed by Fisher's least significant difference (LSD) test $(\alpha=0.05$, LSD $=0.2)$. For each treatment, different letters indicate statistically significant differences $(\alpha=0.05)$. Vertical bars indicate the standard error of the mean. Lane A, B301DR (parental strain); B, BR132 (syrB1 mutant); C, BR208 (sypA mutant); D, BR-DBL1 (syrB1-sypA double mutant); E, BR105 (syrD mutant); F, water control; G, BR208-MR501 (rescued strain). 
The analysis of SypA-M1 correlates with previous studies of peptide synthetases that are responsible for the activation and incorporation of specific amino acids. The amino acid substrate that SypA-M1 specifically recognizes, however, is unknown. The putative substrate-binding pocket of GrsA, the protein responsible for the activation and incorporation of phenylalanine in gramicidin S synthesis, was identified by Xray crystallography (Conti et al. 1997). It was demonstrated that the substrate-binding pocket is located within the amino acid activation domain. We used GrsA as a model to perform an alignment of SypA-M1 to the regions encompassing the putative substrate-binding pockets of SyrB1-M9 and the eight amino acid activation modules of SyrE (Conti et al. 1997; Stachelhaus et al. 1999). A phylogenetic analysis of these substrate-binding regions predicted that SyrE-M1 and SyrEM2 are most similar to each other (Fig. 4). Interestingly, the SyrE-M1 and SyrE-M2 amino acid activation modules were shown by Guenzi et al. (1998) to be responsible for the incorporation of serine, the first two structural amino acids in the syringomycin peptide. This analysis also demonstrated that the SyrE-M3 and SyrE-M4 amino acid activation modules are closely related and predicted to recognize 2,4-diaminobutryic acid as substrate (Guenzi et al. 1998). The phylogenetic analysis indicates that SypA-M1 is most similar to SyrE-M7. The amino acid activation module SyrE-M7 is predicted to be responsible for the incorporation of L-Thr, which is modified to 2,3-dehydroaminobutyric acid (Dhb) in syringomycin (Grgurina and Mariotti 1999). We thus propose that SypA-M1 is the first amino acid activation module of syringopeptin synthesis and is responsible for the incorporation of L-Thr into the syringopeptin structure that is eventually modified to $\mathrm{Dhb}$, the N-terminal amino acid in the syringopeptin molecule (Fig. 1). Grgurina and Mariotti (1999) recently demonstrated that Dhb was formed by 2,3 dehydration of $\mathrm{L}-\left[{ }^{14} \mathrm{C}\right]-\mathrm{Thr}$ in $P$. syringae. Accordingly, a clustering of Thr and Dhb domains supports common substrate specificity, which was observed by the clustering of SyrB1-M9 and SyrE-M7 with SypA-M1 in our analysis (Fig. 4). A similar analysis was completed by Stachelhaus et al. (1999) with the signature sequences they identified from 160 adenylation domains of peptide synthetases from a variety of prokaryotic and eukaryotic organisms. They observed the same clustering of SyrB1-M9 and SyrEM7, and of SyrE-M3 and SyrE-M4 that was observed in our analysis (Fig. 4). A distinct advantage to our phylogenetic analysis is that the evolutionary bias is minimized because 10 substrate-binding regions from a single organism (i.e., $P$. syringae pv. syringae strain B301D) are included. Accordingly, the amino acid sequences encompassing the entire substratebinding region were included in our analysis as opposed to the smaller regions analyzed in other studies (Stachelhaus et al. 1999).

These sypA-syrB1 mutant studies demonstrate that syringopeptin and syringomycin are the major virulence determinants produced by $P$. syringae pv. syringae strain B301D that is pathogenic to Prunus avium and related hosts. The molecular genetic approach allowed specific disruption of one or both of the toxins and enabled us to measure the contribution of each toxin to the virulence of $P$. syringae pv. syringae in vivo. These experiments showed that syringopeptin makes a greater contribution to the virulence of $P$. syringae pv. syringae in immature sweet cherry fruits. More importantly, when neither of the toxins is produced in vivo, the pathogen causes very little necrosis in the plant host. It remains to be determined which components of the compatible interaction of $P$. syringae pv. syringae and its respective host are fundamentally important to pathogenicity. This study provides the foundation for studying the relationship of toxin production to other factors contributing to disease such as the relationship of phytotoxin production to the hrp type III secretion system (Galan and Collmer 1999).

\section{MATERIALS AND METHODS}

Bacterial strains, plasmids, and media.

The bacterial strains used in this study are listed in Table 1 . Escherichia coli strains DH5 $\alpha$ (Hanahan 1985) and HB101 were cultured at $37^{\circ} \mathrm{C}$ in Luria-Bertani (LB) broth or on LB agar (Sambrook J. et al. 1989). P. syringae pv. syringae strains were cultured routinely in nutrient-broth yeast extract (NBY) liquid or agar media (Vidaver 1967) at $25^{\circ} \mathrm{C}$. N-minimal (NM) agar (Vidaver 1967) supplemented with the appropriate antibiotics was used for selection of $P$. syringae pv. syringae transconjugants. The syringomycin bioassays were performed on potato dextrose agar (PDA) supplemented with $0.4 \%$ casamino acids and $20 \mathrm{ml}$ of $1.5 \%$ glucose per plate (Gross and DeVay 1977). The syringopeptin bioassays were performed on $20 \mathrm{ml}$ of peptone-glucose- $\mathrm{NaCl}$ agar (PGNA) per plate (Bultreys and Gheysen 1999). Antibiotics (Sigma Chemical Co., St. Louis, MO, U.S.A.) were added to media as required at the following final concentrations per milliliter: $100 \mu \mathrm{g}$ of ampicillin, $25 \mu \mathrm{g}$ of tetracycline, $25 \mu \mathrm{g}$ of piperacillin, $100 \mu \mathrm{g}$ of rifampin, $100 \mu \mathrm{g}$ of kanamycin, and $100 \mu \mathrm{g}$ of cycloheximide.

\section{Bioassay of $P$. syringae pv. syringae strains for syringomycin and syringopeptin production.}

The $P$. syringae pv. syringae strains were screened for the ability to produce syringomycin with the bioassay described by Gross and DeVay (1977). Briefly, P. syringae pv. syringae strains were grown overnight in $5 \mathrm{ml}$ of NBY liquid medium. Bacterial cells were harvested by centrifugation and washed once with sterile distilled water (SDW). The cells were resuspended in SDW to a concentration of approximately $2 \times 10^{8}$ $\mathrm{CFU}$ per $\mathrm{ml}$, and $5 \mu \mathrm{l}$ aliquots of bacterial suspension were spotted onto PDA plates. The plates were incubated for 4 days at $25^{\circ} \mathrm{C}$ and lightly oversprayed with an arthrospore suspension of the bioassay fungus $G$. candidum F-260, which is sensitive to syringomycin but not syringopeptin (Grgurina et al. 1996; Lavermicocca et al. 1997). The P. syringae pv. syringae mutant strains were compared with the parental strain for formation of zones of antifungal growth inhibition to G. candidum. The $P$. syringae pv. syringae mutant strains were screened for their ability to produce syringopeptin with a bioassay, described by Grgurina et al. (1996), but modified to use PGNA instead of PDA. P. syringae pv. syringae strains were cultured as described above, except the bacterial suspensions were transferred to PGNA plates and incubated for 4 days at $25^{\circ} \mathrm{C}$. The PGNA plates were then oversprayed with a cell suspension of $B$. megaterium $\mathrm{Km}$, which is highly sensitive to syringopeptin (Lavermicocca et al. 1997). The P. syringae pv. syringae mutant strains were compared with the parental strain for formation of zones of bacterial growth inhibition to 
B. megaterium, which is less sensitive to syringomycin. In order to avoid confusion in distinguishing between the syringomycin and syringopeptin inhibition zones, the syringopeptin mutations were introduced into strain BR334 (Zhang et al. 1995). Strain BR344 is a syrC mutant of B301D-R that does not produce syringomycin, but does produce large amounts of syringopeptin (Grgurina et al. 1996), which provides a clear bioassay for syringopeptin.

\section{HPLC analysis and isolation}

\section{of syringomycin and syringopeptin.}

Mutant strains of $P$. syringae pv. syringae were evaluated by HPLC analysis for production of syringomycin and syringopeptin by the methods described by Grgurina et al. (1996). The toxins were isolated and purified from culture filtrates and quantitative measurements of toxin concentrations (nmol per $\mathrm{ml}$ ) were determined by reverse-phase HPLC analysis of metabolites (Grgurina et al. 1996). Elution of the toxins was performed on a $\mathrm{C}_{8}$ reverse-phase column. The solvent gradient was obtained by mixing solvent $\mathrm{A}(0.1 \%$ trifluoroacetic acid [TFA] in water $)$ with solvent $\mathrm{B}\left(0.1 \%\right.$ TFA in $\mathrm{CH}_{3} \mathrm{CN}$ isopropanol 4:1, vol/vol).

Purified preparations of syringomycin and syringopeptin for comparative analysis of phytotoxic activity in immature cherry fruits were prepared by the procedures described by Hutchison and Gross (1997). Briefly, syringomycin and syringopeptin were isolated from cultures of $P$. syringae pv. syringae strains B301D and BR334, respectively. A HPLC system (Waters Corp., Milford, MA, U.S.A.) equipped with a preparative $\mathrm{C}$-18 reverse-phase column (Altex Ultrasphere-ODS, $1 \times 25 \mathrm{~cm}$; Beckman Instruments, Fullerton, CA, U.S.A.) was used to separate the toxin peaks monitored at $\mathrm{A}_{214}$. Individual peaks were collected and tested for biological activity with $G$. candidum F-260 and B. megaterium $\mathrm{Km}$ for detection of syringomycin and syringopeptin, respectively (Grgurina et al. 1996). Peaks corresponding to the various forms of syringomycin ( $\mathrm{SRA}_{1}, \mathrm{SRE}$, and SRG) were pooled before lyophilization and storage at $-20^{\circ} \mathrm{C}$. Syringopeptin forms $\mathrm{SP}_{22} \mathrm{~A}$ and $\mathrm{SP}_{22} \mathrm{~B}$ also were pooled and stored. Prior to testing for phytotoxic activities in immature cherry fruits, the toxin preparations were resuspended in $0.5 \mu \mathrm{g}$ of SDW per $\mu \mathrm{l}$. Immature cherry fruits were wounded at three sites with a 25 -gauge needle and treated with a 5- $\mu$ l droplet at each site.

\section{DNA manipulations and sequence analysis.}

Routine procedures (Sambrook et al. 1989) were used for plasmid isolations from $E$. coli and for restriction endonuclease digestions and subcloning. The 5.1-kb HindIII-EcoRI fragment of pYM1 (Mo and Gross 1991) carrying genomic DNA from $P$. syringae pv. syringae strain B301D was subcloned into pUC18 (Yanisch-Perron et al. 1985), designated pBS008, and a 4-kb region that carries the $5^{\prime}$ end of sypA was sequenced. Sequencing primers were synthesized by GenoSys Biotechnologies Inc. (The Woodlands, TX, U.S.A.). Sequence reactions were completed for both strands of the DNA region with fluorescence-based dideoxy terminators and Ampli-Taq polymerase (Perkin Elmer Applied Biosystems, Norwalk, CT, U.S.A.). Sequence reactions were run on an Applied Biosystems sequencer model 373A (Perkin Elmer Applied Biosystems).

Sequence data were compiled by the GCG Wisconsin Sequence Analysis programs, beta version 9.0 (Genetics Com- puter Group, Madison, WI, U.S.A.) (Devereux et al. 1984). The Fragment Assembly program was used to assemble the nucleotide sequence, Findpatterns to identify Shine-Dalgarno sequences for the translational start site, and GAP to compare the two sequences. BLAST (Altschul et al. 1990) and FASTA were used to identify nucleic acid sequences and proteins homologous to the $5^{\prime}$ portion of the sypA gene and its predicted protein product. Codon usage analysis of the first $3.9 \mathrm{~kb}$ of sypA was performed with the codon usage table 11 in the GCG program and constructed from $P$. syringae pv. syringae sequences present in the database.

The predicted SypA protein sequence was compared with GrsA by GAP to identify an amino acid region (residues 611 to 815) encompassing the substrate-binding pocket within the amino acid activation module (Conti et al. 1997; Stachelhaus et al. 1999). An alignment of the corresponding substratebinding pockets of the amino acid activation modules, SypAM1, SyrB1-M9, and the eight amino acid activation modules of the SyrE protein obtained from GenBank was completed with Clustal-X version 1.8. TreeView version 1.5 (Page 1996) was used to construct a dendrogram.

\section{Mutagenesis of the sypA gene.}

The sypA gene was disrupted by a nonpolar mutation with the nptII gene cloned into pBS008 at a unique EcoRV site located within the sypA gene. The nptII cassette carried on pBSL15 (Alexeyev 1995) lacks a rho-independent transcription terminator and therefore creates nonpolar mutations within an operon. The nptII cassette was removed from pBSL15 by digestion with EcoRI and separated by gel electrophoresis. The nptII cassette was then isolated by Qiaex II gel purification (Qiagen, Chatsworth, CA, U.S.A.) and the ends of the fragment were polished with T4 DNA polymerase. Plasmid pBS008 was linearized with EcoRV, and the nptII cassette was inserted into the site by blunt-end ligation. The mutant construct, designated pBS029, was electroporated into competent cells of DH5 $\alpha$ and transformants were selected on LB agar containing ampicillin and kanamycin, and screened by restriction analysis to verify that pBS029 was a pBS008 derivative carrying the nptII gene. The insertion of the $n p t I I$ gene into the EcoRV site within pBS029 was confirmed by sequencing the insertion site. In addition, a Tn5 insertion carried on pYM5.208 (Y.-Y. Mo and D. C. Gross, unpublished) was identified within sypA. The position of Tn5 insertion 208 was confirmed by sequencing.

\section{Construction of mutant syp and syr genes in $P$. syringae pv. syringae strain B301D by marker-exchange mutagenesis.}

In order to generate sypA mutants of $P$. syringae pv. syringae strains B301D, B301D-R, BR132, and BR334, the plasmids pBS029 and pYM5.208 were introduced into competant cells of the respective strains by electroporation, as described by Zhang et al. (1997), for marker-exchange mutagenesis. Resultant $\mathrm{Km}^{\mathrm{r}}$ colonies were screened for loss of the vector by Southern hybridization (Table 1).

$P$. syringae pv. syringae strain B301D syrB1 and syrD mutants were generated by the marker exchange of plasmids pYM1.132 (Zhang et al. 1995) and pYM1.105 (Quigley et al. 1993) and introduced into competant cells of B301D by electroporation. pBS045 was electroporated into competant cells 
of BR132 to generate a syringopeptin and syringomycin double mutant of $P$. syringae pv. syringae, BR-DBL1. The resul$\operatorname{tant} \mathrm{Pip}^{\mathrm{r}}$ or $\mathrm{Km}^{\mathrm{r}}$ colonies were screened for loss of vector by Southern hybridization (Table 1.) All insertions in P. syringae pv. syringae strains were confirmed by Southern analysis and screened for loss of syringopeptin or syringomycin production.

\section{Recovery of the wild-type sypA genotype by marker rescue.}

Plasmid pYM1 was introduced into BR208 competant cells by electroporation to marker rescue the wild-type genotype and phenotype of these strains. The colonies that grew within $48 \mathrm{~h}$ on NBY were then checked for the ability to grow on NBY or NBY plates supplemented with kanamycin. The colonies that grew only on NBY were screened for the presence of the kanamycin cassette by Southern hybridization. The virulence of resultant strain BR208-MR501 was evaluated as described below.

\section{Virulence assays.}

The virulence of sypA, syrB1, sypA-syrB1 double mutants, and syrD mutants of $P$. syringae pv. syringae strains B301D-R and B301D was evaluated in immature Bing cherry fruits with the use of methods described by Quigley et al. (1993). Bacterial cultures were grown to log phase in NBY broth, harvested by centrifugation $(10,000 \times g$ for $10 \mathrm{~min})$, washed twice in SDW, and resuspended to a concentration of $2 \times 10^{6} \mathrm{CFU}$ per $\mathrm{ml}$ in SDW. Immature cherry fruits were harvested with their stems intact 6 to 8 weeks after pollination, surface sterilized, rinsed with SDW, and allowed to air dry (Gross et al. 1984). Fruitlets were wounded at three sites with a 25-gauge needle, and a $2.5-\mu 1$ droplet of the bacterial suspension (approximately $5 \times 10^{3}$ CFU per droplet) was placed onto each site. The inoculum was pulled into the fruitlet by osmotic tension. Parental strains B301D-R and B301D as well as syrD mutant BR105 (Mo and Gross 1991) were used as controls in addition to fruits treated with a $2.5-\mu$ d droplet of SDW. Ten fruits per treatment were inoculated. The inoculated fruitlets were incubated at high humidity (>90\%) for 4 days at $20^{\circ} \mathrm{C}$. On day 4 , virulence was evaluated at each inoculation site by measuring the diameter of the necrotic lesions in millimeters. The relative virulence of mutant strains was determined in relation to the parental strain. These experiments were completed during the spring in 1998, 1999, and 2000.

Bacterial populations of strains B301D-R (parental), BR132 (syrB1 mutant), BR208 (sypA mutant), BR-DBL1 (syrB1sypA double mutant), and BR105 (syrD mutant) in immature cherry fruits were determined at days 0 and 3 by standard serial dilution plating methods (Mo and Gross 1991). Fruits were ground with a mortar and pestle in $3 \mathrm{ml}$ of phosphate buffer (12.5 mM, pH 7.1). A $0.5-\mathrm{ml}$ sample of the slurry was removed, serially diluted, and plated on NBY agar. At each time point, three replications of three fruits each were harvested per treatment.

\section{Statistical analysis.}

In the cherry fruit assays, virulence was measured as mean lesion size in millimeters and determined from an average of three measurements per fruit and 10 fruits per treatment. Strains were evaluated for virulence in cherry fruits on at least two separate occasions. To report the virulence in immature sweet cherry, the mean of each treatment was standardized relative to the appropriate parental strain B301D-R or B301D and reported as a percentage of virulence relative to the parental strain. Means were compared with the use of Fisher's least significant difference test (Snedecor and Cochran 1980). The error bars were calculated by determining the standard errors of the means for each treatment, consisting of 10 replicates for cherry fruits and three replicates for bioassays. All statistical analyses were performed with SAS software version 6.12 (SAS Institute, Cary, NC, U.S.A.).

\section{ACKNOWLEDGMENTS}

We thank J. M. Raaijamakers and K. L. Schroeder for help with statistical analysis and graphical presentation of the cherry fruit data. We also thank J. D. Soule for critical review of this manuscript. This work was supported by grant 97-35303-4460 from the National Research Initiative Competitive Grants Program of the U.S. Department of Agriculture, Science and Education Administration (D.G.). This work was also supported in part by grants from the "Istituto Pasteur-Fondazione Cenci Bolognetti," Universita di Roma "La Sapienza," and the Italian Ministry of University and Technological Research (MURST) (I.G.). PPNS No. 0309, Department of Plant Pathology, College of Agriculture and Home Economics Research Center, Washington State University, Pullman 99164-6430, USA. This paper is dedicated to the memory of Giacomino Randazzo.

\section{LITERATURE CITED}

Alexeyev, M. 1995. Three kanamycin resistance gene cassettes with different polylinkers. Biotechniques 18:52-56.

Altschul, S. F., Gish, W., Miller, W., Myers, E. W., and Lipman, D. J. 1990. Basic local alignment search tool. J. Mol. Biol. 215:403-410.

Ballio, A., Barra, D., Bossa, F., DeVay, J. E., Grgurina, I., Iacobellis, N. S., Marino, G., Pucci, P., Simmaco, M., and Surico, G. 1988. Multiple forms of syringomycin. Physiol. Mol. Plant Pathol. 33:493-496.

Ballio, A., Barra, D., Bossa, F., Collina, A., Grgurina, I., Marino, G., Moneti, G., Paci, M., Pucci, P., Segre, A., and Simmaco, M. 1991. Syringopeptins, new phytotoxic lipodepsipeptides of Pseudomonas syringae pv. syringae. FEBS Lett. 291:109-112.

Ballio, A., Bossa, F., DiGiorgio, D., Dinola, A., Manetti, C., Paci, M., Scaloni, A., and Segre, A. L. 1995. Solution conformation of the Pseudomonas syringae pv. syringae phytotoxic lipodepsipeptide syringopeptin 25-A-two-dimensional NMR, distance geometry and molecular dynamics. Eur. J. Biochem. 234:747-758.

Bender, C. L., Stone, H. E., Sims, J. J., and Cooksey, D. A. 1987. Reduced pathogen fitness of Pseudomonas syringae pv. tomato $\operatorname{Tn} 5$ mutants defective in coronatine production. Physiol. Mol. Plant Pathol. 30:273-283.

Bender, C. L., Alarcón-Chaidez, F., and Gross, D. C. 1999. Pseudomonas syringae phytotoxins: Mode of action, regulation, and biosynthesis by peptide and polyketide synthetases. Microbiol. Mol. Biol. Rev. 63:266-292.

Bolivar, F., Rodriguez, R. L., Greene, P. J., Betchlatch, M. C., Heynecker, H. L., Boyer, H. W., Crosa, J. H., and Falkow, S. 1977. Construction and characterization of new cloning vehicles: II. A multipurpose cloning system. Gene 2:95-113.

Bradbury, J. F. 1986. Pages 175-177 in: Guide to Plant Pathogenic Bacteria. Commonwealth Agricultural Bureaux, International Mycological Institute, Farnham Royal, U.K.

Bultreys, A., and Gheysen, I. 1999. Biological and molecular detection of toxic lipodepsipeptide-producing Pseudomonas syringae strains and PCR identification in plants. Appl. Environ. Microbiol. 65:19041909.

Caponero, A., Hutchison, M. L., Iacobellis, N. S., Gross, D. C. 1997. Isolation and characterization of mutants of Pseudomonas syringae pv. syringae defective in production of syringopeptins. Pages 202-207 in: Pseudomonas syringae Pathovars and Related Pathogens. K. Rudolph, T. J. Burr, J. W. Mansfield, D. Stead, A. Vivian, and J. Von 
Kietzell, eds. Kluwer Academic Publishers, Dordrecht, The Netherlands.

Cody, Y. S., Gross, D. C., Proebsting, E. L., Jr., and Spotts, R. A. 1987. Suppression of ice nucleation-active Pseudomonas syringae by antagonistic bacteria in fruit tree orchards and evaluations of frost control. Phytopathology 77:1036-1044.

Conti, E., Stachelhaus, T., Marahiel, M. A., and Brick, P. 1997. Structural basis for the activation of phenylalanine in the non-ribosomal biosynthesis of gramicidin S. EMBO J. 16:4174-4183.

Dalla Serra, M., Fagiuoli, G., Nordera, P., Bernhart, I., Della Volpe, C., Di Giorgio, D., Ballio, A., and Menestrina, G. 1999. The interaction of lipodepsipeptide toxins from Pseudomonas syringae pv. syringae with biological and model membranes: A comparison of syringotoxin, syringomycin, and two syringopeptins. Mol. Plant-Microbe Interact. 12:391-400.

deCrécy-Lagard, V., Marlière, P., and Saurin, W. 1995. Multienzymatic non ribosomal peptide biosynthesis: Identification of the functional domains catalysing peptide elongation and epimerisation. C. R. Acad. Sci. Paris 318:927-936.

Devereux, J., Haeberli, P., and Smithies, O. 1984. A comprehensive set of sequence analysis programs for the VAX. Nucleic Acids Res. 12:387-395.

Fernández-Moreno, M. A., Martínez, E., Boto, L., Hopwood, D. A., and Malpartida, F. 1992. Nucleotide sequence and deduced functions of a set of cotranscribed genes of Streptomyces coelicolor A3(2) including the polyketide synthase for the antibiotic actinorhodin. J. Biol. Chem. 267:19278-19290.

Fogliano, V., Gallo, M., Vinale, F., Ritieni, A., Randazzo, G., Greco, M., Lops, R., and Graniti, A. 1999. Immunological detection of syringopeptins produced by Pseudomonas syringae pv. lachrymans. Physiol. Mol. Plant Pathol. 55:255-261.

Fukuchi, N., Isogai, A., Nakayama, J., Takayama, S., Yamashita, S., Suyama, K., Takemoto, J. Y., and Suzuki, A. 1992. Structure and stereochemistry of three phytotoxins, syringomycin, syringotoxin and syringostatin, produced by Pseudomonas syringae pv. syringae. J. Chem. Soc. Perkin Trans. I. 9:1149-1157.

Galan, J. E., and Collmer, A. 1999. Type III secretion machines: Bacterial devices for protein delivery into host cells. Science 284:13221328.

Gocht, M., and Marahiel, M. A. 1994. Analysis of core sequences in the D-phe activation domain of the multifunctional peptide synthetase TycA by site-directed mutagenesis. J. Bacteriol. 176:2654-2662.

Grgurina, I., and Benincasa, M. 1994. Evidence of the non ribosomal biosynthetic mechanism in the formation of syringomycin and syringopeptin, bioactive lipodepsipeptides of the phytopathogenic bacterium Pseudomonas syringae pv. syringae. Ital. Biochem. Soc. Trans. $5: 143$

Grgurina, I., and Mariotti, F. 1999. Biosynthetic origin of syringomycin and syringopeptin 22 , toxic secondary metabolites of the phytopathogenic bacterium Pseudomonas syringae pv. syringae. FEBS Lett. 462:151-154.

Grgurina, I., Gross, D. C., Iacobellis, N. S., Lavermicocca, P., Takemoto, J. Y., and Benincasa, M. 1996. Phytotoxin production by Pseudomonas syringae pv. syringae: Syringopeptin production by syr mutants defective in biosynthesis or secretion of syringomycin. FEMS Microbiol. Lett. 138:35-39.

Grgurina, I., Iacobellis, N. S., Ippolito, C., Curci, R. 1997. Detection of syringomycin in plant tissues infected with Pseudomonas syringae pv. syringae. Pages 188-191 in: Pseudomonas syringae Pathovars and Related Pathogens. K. Rudolph, T. J. Burr, J. W. Mansfield, D. Stead, A. Vivian, and J. Von Kietzell, eds. Kluwer Academic Publishers, Dordrecht, The Netherlands.

Gross, D. C. 1991. Molecular and genetic analysis of toxin production by pathovars of Pseudomonas syringae. Annu. Rev. Phytopathol. 29:247-278.

Gross, D. C., and DeVay, J. E. 1977. Population dynamics and pathogenesis of Pseudomonas syringae in maize and cowpea in relation to the in vitro production of syringomycin. Phytopathology 67:475-483.

Gross, D. C., Cody, Y. S., Proebsting, E. L., Jr., Radamaker, G. K., and Spotts, R. A. 1984. Ecotypes and pathogenicity of ice-nucleationactive Pseudomonas syringae isolated from deciduous fruit tree orchards. Phytopathology 74:241-248.

Gross, D. C., Scholz-Schroeder, B. K., Zhang, J. H., Grgurina, I., Mariotti, F., Della Torre, G., Guenzi, E., and Grandi, G. 1998. Char- acterization of the thiotemplate mechanisms of syringomycin and syringopeptin synthesis by Pseudomonas syringae pv. syringae. Pages 91-98 in: Molecular Genetics of Host Specific Toxins in Plant Diseases. K. Kohmoto and O. C. Yoder, eds. Kluwer Academic Publishers, Dordrecht, The Netherlands.

Guenzi, E., Galli, G., Grgurina, I., Gross, D. C., and Grandi, G. 1998. Characterization of the syringomycin synthetase gene cluster-A link between prokaryotic and eukaryotic peptide synthetases. J. Biol. Chem. 273:32857-32863.

Hanahan, D. 1985. Techniques for transformation of E. coli. Pages 109 135 in: DNA Cloning: A Practical Approach, Vol. 1. D. M. Glover, ed. IRL Press, Washington DC.

Hori, K., Yamamoto, Y., Minetoki, T., Kurotsu, T., Kanda, M., Miura, S., Okamura, K., Furuyama, J., and Saito, Y. 1989. Molecular cloning and nucleotide sequence of the gramicidin $\mathrm{S}$ synthetase 1 gene. J. Biochem. (Tokyo) 106:639-645.

Hutchison, M. L., and Gross, D. C. 1997. Lipopeptide phytotoxins produced by Pseudomonas syringae pv. syringae: Comparison of the biosurfactant and ion channel-forming activities of syringopeptin and syringomycin. Mol. Plant-Microbe Interact. 10:347-354.

Hutchison, M. L., Tester, M. A., and Gross, D. C. 1995. Role of biosurfactant and ion channel-forming activities of syringomycin in transmembrane ion flux: A model for the mechanism of action in the plantpathogen interaction. Mol. Plant-Microbe Interact. 8:610-620.

Iacobellis, N. S., Lavermicocca, P., Grgurina, I., Simmaco, M., and Ballio, A. 1992a. Phytotoxic properties of Pseudomonas syringae pv. syringae toxins. Physiol. Mol. Plant Pathol. 40:107-116.

Iacobellis, N. S., Lavermicocca, P., Surico, G., and Durbin, R. D. 1992b. The occurrence and characterization of a syringomycinmacromolecular complex in cultures of Pseudomonas syringae pv. syringae. Physiol. Mol. Plant Pathol. 40:91-105.

Kauss, H., Waldmann, T., Jeblick, W., and Takemoto, J. Y. 1991. The phytotoxin syringomycin elicits $\mathrm{Ca}^{2+}$-dependent callose synthesis in suspension-cultured cells of Catharanthus roseus. Physiol. Plant 81:134-138.

Lavermicocca, P., Iacobellis, N. S., Simmaco, M., and Graniti, A. 1997. Biological properties and spectrum of activity of Pseudomonas syringae pv. syringae toxins. Physiol. Mol. Plant Pathol. 50:129-140.

Marahiel, M. A. 1992. Multidomain enzymes involved in peptide synthesis. FEBS Lett. 307:40-43.

Marahiel, M. A., Stachelhaus, T., and Mootz, H. D. 1997. Modular peptide synthetases involved in nonribosomal peptide synthesis. Chem. Rev. 97:2651-2673.

Menkhaus, M., Ullrich, C., Kluge, B., Vater, J., Vollenbroich, D., and Kamp, R. M. 1993. Structural and functional organization of the surfactin synthetase multienzyme system. J. Biol. Chem. 268:7678-7684.

Mo, Y.-Y., and Gross, D. C. 1991. Expression in vitro and during plant pathogenesis of the $s y r B$ gene required for syringomycin production by Pseudomonas syringae pv. syringae. Mol. Plant-Microbe Interact. 4:28-36.

Mott, K. A., and Takemoto, J. Y. 1989. Syringomycin, a bacterial phytotoxin, closes stomata. Plant Physiol. 90:1435-1439.

Page, R. D. M. 1996. TREEVIEW: An application to display phylogenetic trees on personal computers. Comput. Appl. Biosci. 12:357-358.

Paynter, V. A., and Alconero, R. 1979. A specific antibody for detection of syringomycin in infected peach tree tissues. Phytopathology 69:493-496.

Peet, R. C., Lindgren, P. B., Willis, D. K., and Panopoulos, N. J. 1986. Identification and cloning of genes involved in phaseolotoxin production by Pseudomonas syringae pv. "phaseolicola." J. Bacteriol. 166:1096-1105.

Prentki, P., Karch, F., Iida, S., and Meyer, J. 1981. The plasmid cloning vector pBR325 contains a 482 base-pair-long inverted duplication. Gene 14:289-299.

Quigley, N. B., and Gross, D. C. 1994. Syringomycin production among strains of Pseudomonas syringae pv. syringae: Conservation of the $s y r B$ and $s y r D$ genes and activation of phytotoxin production by plant signal molecules. Mol. Plant-Microbe Interact. 7:78-90.

Quigley, N. B., Mo, Y. Y., and Gross, D. C. 1993. SyrD is required for syringomycin production by Pseudomonas syringae pathovar syringae and is related to a family of ATP-binding secretion proteins. Mol. Microbiol. 9:787-801.

Sambrook J., Frisch, E. F., and Maniatis, T. 1989. Molecular Cloning: A Laboratory Manual. Cold Spring Harbor Laboratory Press, Cold 
Spring Harbor, NY, U.S.A.

Saraste, M., Sibbald, P. R., and Wittinghofer, A. 1990. The P-loop: A common motif in ATP- and GTP-binding proteins. Trends Biochem. Sci. 15:430-434.

Segre, A., Bachmann, R. C., Ballio, A., Bossa, F., Grgurina, I., Iacobellis, N. S., Marino, G., Pucci, P., Simmaco, M., and Takemoto, J. Y. 1989. The structure of syringomycins $A_{1}, E$ and G. FEBS Lett. 255:27-31.

Snedecor, G., and Cochran, W. 1980. Statistical Methods. Iowa State University Press, Ames, IA, U.S.A.

Stachelhaus, T., and Marahiel, M. A. 1995. Modular structure of genes encoding multifunctional peptide synthetases required for nonribosomal peptide synthesis. FEMS Microbiol. Lett. 125:3-14.

Stachelhaus, T., Mootz, H. D., and Marahiel, M. A. 1999. The specificity-conferring code of adenylation domains in nonribosomal peptide synthetases. Chem. Biol. 6:493-505.

Stein, T., and Vater, J. 1996. Amino acid activation and polymerization at modular multienzymes in nonribosomal peptide biosynthesis. Amino Acids 10:201-227.

Turgay, K., Krause, M., and Marahiel, M. A. 1992. Four homologous domains in the primary structure of GrsB are related to domains in a superfamily of adenylate-forming enzymes. Mol. Microbiol. 6:529546

Vidaver, A. K. 1967. Synthetic and complex media for the rapid detection of fluorescence of phytopathogenic pseudomonads: Effect of the carbon source. Appl. Microbiol. 15:1523-1524.

Xu, G.-W., and Gross, D. C. 1988. Physical and functional analyses of the $s y r A$ and $s y r B$ genes involved in syringomycin production by Pseudomonas syringae pv. syringae. J. Bacteriol. 170:5680-5688.

Yanisch-Perron, C., Vieira, J., and Messing, J. 1985. Improved M13 phage cloning vectors and host strains: Nucleotide sequences of the M13mp18 and pUC19 vectors. Gene 33:103-119.

Zhang, J.-H., Quigley, N. B., and Gross, D. C. 1995. Analysis of the syrB and syrC genes of Pseudomonas syringae pv. syringae indicates that syringomycin is synthesized by a thiotemplate mechanism. J. Bacteriol. 177:4009-4020.

Zhang, J.-H., Quigley, N. B., and Gross, D. C. 1997. Analysis of the syrP gene, which regulates syringomycin synthesis by Pseudomonas syringae pv. syringae. Appl. Environ. Microbiol. 63:2771-2778. 